\title{
Ethical Behaviour and Compliance with Donor Reporting Requirements by Non-Governmental Organisations in Uganda: A Proposition
}

\author{
Moses Kusemererwa Festo Nyende Tusubira* Gerald Kasigwa \\ Department of Accounting and Finance, College of Business and Management Sciences, Makerere University, \\ P.O. Box 7062, Kampala, Uganda
}

\begin{abstract}
This study seeks to respond to the question of dwindling donor generosity in the face of the UN sponsored sustainable development goals and Uganda's Vision 2040. Recently, most donors who support poverty alleviating efforts through the medium of Non-Governmental Organisations, have been scaling down on some of their commitments. This seems to persist even as the need for humanitarian and development aid is increasing due to neighborhood immigrations and the resulting resource competitions. Ideally, donor step back should be undesirable at this time, and any cause for the same should be established and checked. Scholars suggest managerial incentives could be at play. This study is set out to examine the relationship that exists between ethical behaviour and NGO compliance with donor reporting requirements in Uganda. The study objectives will identify the various donor reporting requirements and investigate some ethical behaviour that impede NGOs' compliance with the donors' reporting requirements. To address the question of why donor fatigue at such a time of need, the researchers propose to engage with donor agencies, national NGO regulators and NGO senior management teams, for their input into the response. The stakeholder views obtained will be available for integration into the national regulatory framework to rejuvenate donor trust and socio-economic participation of the NGO sector in Uganda.
\end{abstract}

Keywords: ethical behaviour, compliance, donor reporting requirements, NGOs, Uganda

DOI: $10.7176 /$ RJFA/11-22-07

Publication date: November $30^{\text {th }} 2020$

\section{Introduction}

The article proposes to examines the relationship between ethical behaviour and compliance with donor reporting requirements by Non-Governmental Organisations (NGOs) in Uganda. This chapter presents a background to the problem, the problem statement, outlines the purpose \& objectives of the study, research questions, as well as stating the conceptual framework, the scope and significance of the study.

\subsection{Background}

The issue of compliance has grown with higher funding and the increasing number of NGOs that represent the third sector of the global economy. The sector has enthusiastically expanded as a result of donors initially perceiving it as more effective and efficient in tackling the global poverty challenge (Meyer, 1992). The NGOs are a highly preferred medium of transferring aid to fight poverty, disease and ignorance (Dupuy \& Prakash, 2017). Scholars believe this is due to its non-profit motive driven by a charitable purpose (Barr, Fafchamps \& Trudy, 2003). The sector is also viewed as having the potential to fill the gaps left by governments' bureaucratic red tape (Abraham 2003: 5), private sector profit motives and labour unions' conflict of interest (Not-for-Profit Quarterly, 2018). Ideally, NGOs should be more effective, efficient and accountable to stakeholders than those entities.

The African continent has 36 out of 39 (92.3\%) countries highly dependent on foreign aid. Most of this aid is channelled via the medium of NGOs (Yakubu, 2016). Because of aid dependency, the sector has tremendously grown on the continent. Uganda's NGO sector has not been exception (Damba, 2018; MIA Press Release, 7th August 2019). As of September $7^{\text {th }}, 2019$, the number is impressively high (14,027 NGOs) (Daily Monitor 15 th Nov, 2019). However, their effectiveness, efficiency and accountability do not match classical expectations! As it were, this raises risk levels and more stringent donor reporting requirements for the sector to comply (Lehman, 2007; Bottiglieri et al., 2011; Humanitarian Financing Task Team, 2016; Joint Inspection Unit, 2017).

The risk is mainly fuelled by the financial scandals at the beginning of the century that have shaken donor confidence. Examples of donors with explicit rules for using and reporting their funds include United States government (USG), United Kingdom (UK), European Union (EU) and German (USAID Report, 2010; All European Academies, 2013; UNHCR bipartite model, 2014). The donor regulations tend to proportionately increase with extra investment in NGO interventions (White, 2017) and create legal, social and ethical obligations to operate and report credibly to all stakeholders.

Unfortunately, the NGO sector in Uganda is pictured as engulfed "in a credibility crisis" due to noncompliance with the donor reporting requirements (Omona \& Mukuye 2012). This seems to relate to a breakdown in issues of governance, financial management and due diligence. Allegations of corruption \& misappropriation 
of resources are no longer news in Uganda. The media is awash with reports of "outright theft" \& "massive financial mismanagement," some of which involve staff taking huge sums of money (Sunday Monitor, June 9 2019: 8). This may be evidence that donors' basic reporting requirements are rarely prioritised.

The government of Uganda has enacted laws and set up institutions to enable the sector remain compliant. This is in recognition of the sector's contributions to government efforts in pursuit of Vision 2040, which requires input from all players (CEO Forum, 2018: 27). The facilitation can be seen from the sectoral theme for the financial years 2015/16 - 2019/20: "Positioning the National Bureau for NGOs to drive a vibrant, accountable and more effective NGO sector" (National Bureau of NGOs, 2019). In addition, donor agencies support NGOs in training staff (Joint Inspection Unit (2017: 13), periodic compliance visits and pre-qualifying them to piggyback on exemptions negotiated with government (UNHCR bipartite model, 2014: Art. 11.5). The objective is to facilitate the sector become more accountable to stakeholders and accelerate economic welfare of Ugandans. Whether this is working, is still a million-dollar question.

Due to the alleged fraudulent practices, some donors threaten to scale down funding (Daily Monitor, 8th February 2018). Already, Democratic Governance Facility (DGF) stopped funding of four NGOs over misuse of funds, and indefinitely suspended other potential contracts (DGF, 21st June 2019). This implies reducing goodwill for the sector in the country. A case in point is the limited funds raised so far for the Comprehensive Refugee Response Framework (CRRF). The United Nations High Commissioner for Refugees (UNHCR) global plans are usually 54\% funded. But in Uganda, the agency's emergency plan in 2017 was only 29\% funded; the solidarity summit, targeting \$2bn raised a mere \$350m (17.5\%)! while the South Sudanese emergency appeal by the same agency fetched 16\% only (International Rescue Committee, 2018: 10). All this is due to fraud allegations levelled against the agency.

There might be at play some ethical flaws in managerial behaviour such as "fabrication, falsification, plagiarism, \& unjustified double funding" (The European Research Administrators, 2017). Despite providing the well-established notions of what is good practice, NGOs in Uganda still grapple with non-compliance. Fraudulent behaviour could ideally be on increase (Othman \& Ali, 2012). If this trend is not abated, Uganda will lose about 500,000 jobs and billions in taxes (New Vision January 20,2020). This could easily kill the sector in the country (Daily Monitor, 27th February 2020)! According to Wandera (2012), such is "unacceptably shameful and must be stopped in the greater interest of all Ugandans". This study will examine the relationship between ethical behaviour and compliance with donor reporting requirements by NGOs in Uganda.

\subsection{Problem statement}

An increase in foreign aid channelled through NGOs apparently triggers donors' greater demand for accountable, effective and efficient use of the resources donated (Joint Inspection Unit, 2017). To achieve this, donor agencies institute explicit reporting requirements for the resources given. The poor media publicity about the sector in Uganda suggest a persistent non-compliance with these requirements on ethical grounds (Sunday Monitor June 9, 2019). The clear-cut donor demands (Humentum, 2019) and improved government regulatory environment (NGO Act 2016: S.36), have not improved the situation (CSO Sustainability Index 2017). The likely effect will be donors' withdrawal, resulting in Ugandans losing jobs, target beneficiaries deprived of livelihood and the country missing out on the economic contributions the sector offers (National Bureau of NGOs, 2019). The proposition of this study is therefore to investigate the relationship between ethical behaviour and compliance with donors' reporting requirements of NGOs in the country.

\subsection{Purpose of the study}

The purpose of this study is to examine the relationship between ethical behaviour and compliance with donor reporting requirements by NGOs in Uganda

\subsection{Specific objectives}

a) To identify the various donors reporting requirements governing NGOs in Uganda

b) To investigate the ethical behaviour affecting NGOs' compliance with donors reporting requirements in Uganda

c) To examine the relationship between ethical behaviour and compliance with donors reporting requirements by NGOs in Uganda.

\subsection{Research questions}

a) What are the various donors reporting requirements governing NGOs in Uganda?

b) Which ethical behaviour affect compliance with donor reporting requirements by NGOs in Uganda?

c) How do ethical behaviour affect compliance with donor reporting requirements among NGOs in Uganda?

\subsection{Conceptual framework}

This conceptual framework represents the relationship between ethical behaviour and compliance with donors' 
reporting requirements. The study conceptualizes that behaving ethically is very crucial in facilitating donation managers to comply with donor reporting requirements. This coupled with competent staffing results in producing complete, accurate \& timely donor reports for sustainable funding.

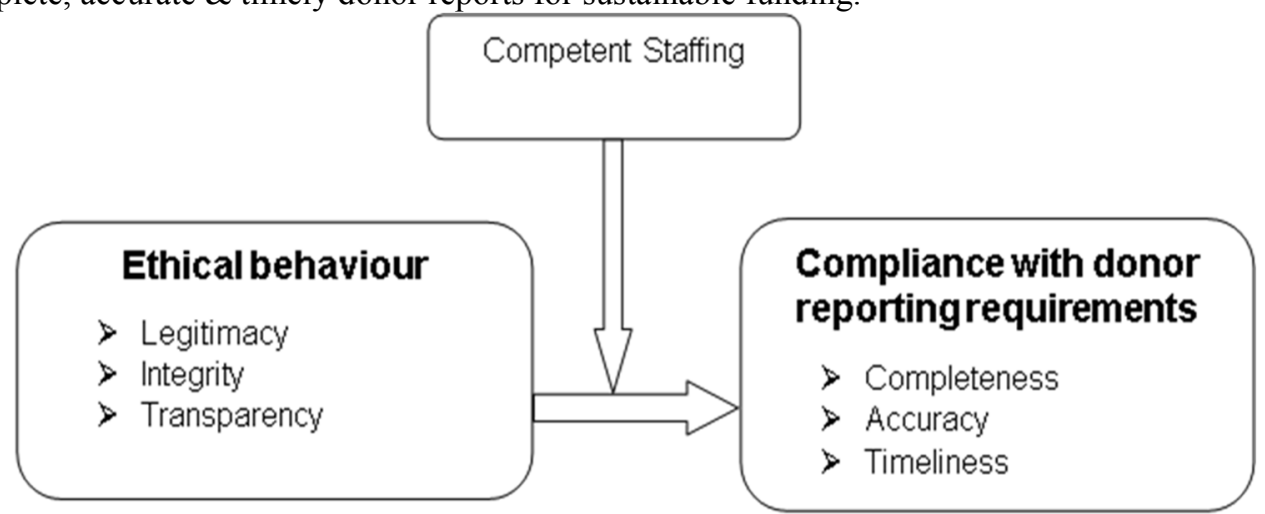

Source: Adapted from Managing for Impact in Rural Development; A Guide for Project $M$ \& E, International Fund for Agricultural Development (IFAD), 2002

The relationship between the causal factor (ethical behaviour) and compliance with donor reporting requirements will be examined by investigating the elements of ethical behaviour in the model above. The impact of these elements on compliance takes into account competent staffing as a moderating variable. This implies that even with legitimacy, integrity and transparency, a certain level of non-compliancy with donor reporting requirements could still exist in case of incompetent staff.

\subsection{Scope of the study}

The study focuses on the relationship between ethical behaviour and compliance with donor reporting requirements by NGOs in Uganda. this will focus on Kampala and Wakiso Districts in Uganda where most NGOs are concentrated for a point in time.

\subsection{Significance of the study}

First of all, the NGOs will use the study findings to regulate their members' ethical conduct for continued donor funding and survival. Secondly, the study will inform policy makers in their pursuit of an appropriate policy strategy for effective NGO sector in Uganda and beyond. Lastly, the study is also expected to add on the existing body of knowledge on the subject of complying with donor reporting requirements as examined in institutions of higher learning, research based institutions and upcoming researchers. The subsequent sections will cover; the review of relevant literature and the methodology to be used in the later stage of the study.

\section{Literature review and hypothesis development}

This chapter reviews literature related to the objectives of study to examine the relationship between ethical behaviour and compliance with donor reporting requirements by NGOs in Uganda. Specifically, it defines compliance as a derivative of ethical behaviour; identifies the various donor reporting requirements; establishes ethical behavioural measures, together with competent staffing and examines how these factors drive compliance with donor reporting requirements.

\subsection{Theoretical review on compliance}

As a study concept, compliance is derived from what individuals, organisations, society and professional codes of conduct consider to be good practice. However, convergence on these parameters is very relative. This study finds two theories very relevant in understanding the concept of compliance - the theory of positive accounting and public interest theory. Consider the two theories in order.

The positive accounting theory was advanced by Ross (1978) and later improved by Watts \& Zimmerman (1986). The theory developed from two economic foundation theories - the efficient market hypothesis and the agency theory (Llott, 2017). These theories paint managers as incorporating personal interests while adopting accounting policies to serve stakeholders (Mukokoma \& Tushabomwe, 2019). Acting in self-interest though may not be for managers only but also other stakeholders like employees, creditors or government, given chance. Because accounting Standards set only the floor but not the ceiling regarding what and what not to declare in financial reports, "managers are free to make whatever disclosures they see fit". Using this IFRS model, managers are likely not to act in good faith towards some weaker stakeholders like the beneficiaries of NGO activities. Thus donors' reporting requirements are intended to elicit compliance that results in transparency and integrity of financial information to the best interest of beneficiaries. But the donors themselves may not be exempt from 
manipulation, hence the government demands for registration "legitimizes" NGOs for ease of control and to the safety of the investing donors.

In addition, the public interest (helping hand) theory of regulation was proposed by Pigou (1938) and adopted by Kumekawa (2017). The theory is underpinned by two key assumptions - unhindered markets fail due to monopoly or externalities; and that government is begnin to and capable of correcting these market failures through regulation. Supporters of this theory argue that government imposes safety standards to prevent accidents like fires, mass poisonings due to poor products, and regulates jobs to limit employers' power over employees, among others. The theory of public interest regulation thus becomes a cornerstone of modern welfare economic principles where beneficiaries are too weak to hold NGO managers to account. Donors call the managers to order by requiring integrity measures to be in place before funding, and transparency of transactions via stakeholder involvement.

In both theories, the element of susceptibility to exploitation due to managers' unethical behaviour may be mitigated by donor and government regulation. Ideally, this is the framework of compliance as a concept- to tame managerial ethical behaviour and achieve multiple stakeholder interests. Broadly speaking, compliance in the $21 \mathrm{st}$ Century goes beyond responding to donor requirements. It may be in form of adhering to environmental laws, workplace safety regulations, nuclear non-proliferation treaties, social responsibility, among other aspects. According to Badaru (2012:12) there is no single definition of compliance as a concept. She specifically however defines compliance as "adherence to reporting requirements in terms of accuracy, completeness and timeliness". This definition of compliance is narrowed to fit her dependent variable of reporting requirements, which makes it limited. It would imply that compliance is just a response to a set of legal regulations, professional standards, and operational requirements, which is partly true.

McGann \& Johnstone (2006) defined compliance as "a state of being in accordance with established guidelines, specifications, or legislation". This is perhaps more convincing. This definition envisages a situation in which an entity, person or organisation, is ideally compatible with existing authority legitimately established. The view is that compliance should not only come from avoiding perceived negative consequences of breach but from a state of mind that believes it's a good thing to comply (Turyakira, 2018). This is perhaps what Okafor (2011) and Riley (2012) had in mind when they expressed compliance as conducting activities in a morally upright manner with positive observable behaviour. Compliance is thus derived from a set of factors. According to Tusubira (2018), trust and perceived fairness may yield compliance. This implies that the race for compliance should focus on the organism before the organisation.

Consider an organisation in Uganda which submitted fuel consumption receipts that quoted vehicle number plates not belonging to their fleet but to heavy duty-trucks in a travel expense accountability (Daily Monitor, JUNE $92019)$ ! The mentality behind this action is just adhering to reporting requirements but does not come from a state of mind that believes accountability is "a good thing to" do. Ethics \& Compliance Initiative (2019: 5) emphasizes that individual Managers establish ethics culture and "their behavior serves as a proxy for the values and priorities" in organisations. The implication is that managers can, by their conduct, set organisational norms and signal the application of certain ethical principles to be followed by staff. According to Knott (2020), individuals cannot label themselves compliant but the truth loving stakeholders who observe their daily conduct overtime, can label them. Therefore, this study defines compliance as a process of aligning organisational activities and ethical management practice with legitimate stakeholder expectations.

\subsection{Donor reporting requirements}

In the context of this study, donor reporting requirements are standards, principles or guidelines contractually agreed upon by donors and implementing partners (IPs) to be followed when reporting project progress and financials. Many believe that funding NGOs for their noble cause in alleviating poverty, protecting human rights, preserving the environment, and providing relief (McGann \& Johnstone, 2006; Poole, 2019) would increase further if only donors could be assured of donations being utilized properly (Zainon et al., 2011). As it turns out to be, some NGOs give wrong data while others tender in insufficient data, all of which strain the donor-NGO relations. This is the genesis of explicit reporting requirements to create uniformity on the completeness, accuracy and timeliness continuum (Humentum, 2019).

Okiror (2019) identifies the United States, the United Kingdom, the European Union and Germany as the biggest donors (contributing $80 \%$ of humanitarian aid to Uganda's refugees). These and other donors tend to give explicit reporting requirements which must be followed (Murage, 2017; Democratic Governance Facility, 2019). The number of reports required also tends to increase with increased donor funding. In 2015 for example, the United Nations agencies received more $\$ 8$ billion specified contributions and the individual donor reports increased from 1,000 to 3,000 in 2016 (Joint Inspection Unit, 2017:30). The need for harmony lays down report features such as content, nature, presentation media, level of scrutiny, best practices, and penalties in case of failure, among others.

Generic donor reporting requirements primarily cover narrative (also called programmatic) reports and financial 
reports. Article 5 of UNHCR bipartite model (2014) explicitly requires partners to "submit timely, accurate and complete reports", whatever the frequency of the reports.

2.2.2 Narrative reports

These are project progress reports, showing the extent to which the project meets objectives. The narrative reports give a simple history of the project plan and move to output results (Detiger, 2018). NGOs are required to prepare and make available these reports of their interventions (Badaru, 2012) to stakeholders (donors, regulators, beneficiaries, and society). The reports should show the effectiveness and efficiency with which donor funds have been used (Kanaga, 2018). Some donors will even provide templates for narrative reports while others just require that organisations use internal formats. However, all donors desire specific content (completeness), accuracy and timeliness of these reports.

2.2.3 Reporting financials

There is no specific accounting standard for NGOs in Uganda. However, they are expected to comply with generally accepted accounting practices adopted, their articles of associations plus national financial reporting regulations relating to NGOs (NGO Act 2016: S.39). The reporting scope covers the generic financial statements under IAS 1 or IPSAS 1: Preparation and presentation of financial statements. These specifically include income \& expenditure; receipts \& payments; monthly bank reconciliation; personnel reports (aggregated payroll) and goods \& property (UNHCR Bipartite Model, 2014: Art. 10.49).

In Uganda, NGO financial reports must be submitted to National Bureau of NGOs within 8 months after the project financial year (NGO Act 2016: S.39). Donor agencies like UNHCR require quarterly reports and a final annual report 15 days after the reporting/liquidation period. The liquidation period is normally a month after implementation year (UNHCR Bipartite Model, 2014: Art.5.1-7). This implies that if the implementation period ended on 31st December, then the liquidation period would end 31st January and the final reporting deadline on 15th February, the following financial year. However, the USAID requires monthly reports that must be submitted on or before the 5th day of the month after the reporting period (Badaru, 2012).

\subsubsection{Documentation}

The EU requires financial documents should be original to avoid duplication and increase information reliability (ECHO FPA, 2014: Art 10. 2. c, d). The UN system requires that narrative and financial reports be duly supported with necessary documents bearing project symbols to avoid accountability duplication while reporting to multiple donors. Project records should be retained for at least 6 years (UNHCR Bipartite Model, 2014). In Uganda, NGO transactions must be fully documented for purposes of filing tax returns (NGO Act, 2016: S.39 (1) (a)), and the documents archived for 5 years (Income Tax Act, 1997: S.129 (3) as amended). This is a key reporting requirement for all donors. The annual reports may be submitted electronically, with accompanying documentation not later than 6 months of the financial year-end (ECHO FPA, 2014: Art. 6. 2. b).

2.2.5 Due diligence

NGOs are required to vet vendors \& partners or be vetted by donors (UNHCR Bipartite Model, 2014: Art 8.2, 10.8) for compliance with United Nations Security Council resolution 1267, relating to financing of terrorism and other money laundering legislations. This is binding on all donors, and NGOs must ensure that donor funds received do not end up in the hands of entities or individuals on blacklists maintained by the United Nations Security Council Sanctions Committee. The requirement also seeks to ensure that NGO staff avoid conflict of interest while carrying out project procurement activities. Donors include due diligence clauses in funding contracts, which require background checks, effective segregation of duties, and identifying appropriate risk responses, in all procurements undertaken. Accordingly reporting NGOs must attach a list of vendors as part of their general ledger (ECHO FPA, 2014: Art. 5. f.ii). The objective is to avoid empowering global terrorism and ensure value for money in contracts management.

2.2.6 Best practices

There are best practices on donor cross-cutting issues of interest that NGO reports should highlight for them to be deemed complete. The issues include affirmative action on impartiality, gender \& disability involvement, (UNHCR Bipartite Model, 2014: Art. 10.42), capacity building, environmental protection, respect for human rights, and documenting lessons learned (ECHO FPA, 2014: Art. 3.2) and fighting child labour (Azia, 2018) in the Uganda Country Refugee Response Plan. This also requires consulting with project beneficiaries and stakeholders to seek their participation in project design (UNHCR, 2014) as noted in Article 7 of the UNHCR Bipartite Model.

2.2.7 Separate bank account

An NGO is required to operate a separate bank account for purposes of accurately and transparently reporting project funds (NGO Act, 2016:46). It must be in the official name of the NGO as quoted in the framework agreement, preferably interest bearing and that any interest earned on the account should be credited to the donor. In case of pooled accounts, interest shall be apportioned in accordance with the size each project contributed into the account. However, pooling of multiple donor funds into a single account can only be donor-authorised (UNHCR, 2014). 


\subsubsection{Official variation waiver}

NGOs donor reporting requirements must drive every action (Anderson, 2014). Even in circumstances where deviation looks logical, the organisation must seek formal authorisation (variation waiver) to do so. As a general rule, a copy of the waiver should be available as a note on file to support a payment voucher for reporting \& audit purposes. Otherwise the NGO will not be seen to have acted accurately.

\subsubsection{Penalty Clause}

The reporting requirements bind all reporting entities, breach of which negatively affects future fundraising efforts, could lead to withdraw of funding or result in refund penalties (Care International, 2017; UNHCR, 2014: Art.10.16). USAID emphasizes that "The USG reserves the right to require refund of any amount that is not spent in accordance with the terms and conditions of the award" (USAID SOPs, 2010). But most donors allow for a discretionary $15 \%$ spending over and above a budget line, either at the objective, output or account level, "provided there is no change to Partner Personnel costs and the overall Project Budget". However, such transactions are subject to a variation waiver to be considered accurate.

\subsection{Ethical behaviour expected of NGOs}

Ethical behavior refers to a process of "acting in ways that are consistent with what society, individuals, and businesses generally accept as good values" (Price, 2017). It generally provides a "moral compass" to the right answers when managers are confronted with technical complexities, competing priorities and conflicting demands (Buberl, 2018:2). Behaving ethically is reflected in the quality of managerial response to the demands of legislation, socio-industrial norms, professional standards, and contractual obligations. Abiodun and Oyeniyi (2014) specifically identify legitimacy, integrity, transparency, accountability, environmental responsibility, fairness, and stakeholder concerns as measures of ethical behaviour. Mayanja and Perks (2018) add meeting legal operational requirements, stakeholder expectations, and industry norms as measures of ethical behaviour among SMEs in Uganda. Media power (freedom) is used to test these measures through objective reporting.

The International Accounting Standards Board echoes the same measures as fundamental principles of relevance and fair presentation (IASB Framework, 2018). Ideally, failure to uphold these principles reflects unethical behaviour. Accountants argue that organisation's information is considered relevant if it's accurately complete and timely, and is fairly presented if it is reliable, comparable, verifiable, and understandable. The underlying principle is that the reporting entity must be legitimate (legal personality) and that management should be of integrity and transparency. Actually, Prestol-Puesan (2020) portrays integrity and transparency as essential traits universally expected of people who live public lives.

In light of the above, this study investigates some ethical behavioural measures of legitimacy, integrity and transparency among NGO managers in Uganda and how they affect compliance with donor reporting requirements. 2.3.1 Legitimacy

The Oxford English Dictionary defines legitimacy as the "condition of being in accordance with the law or principle... or conformity to sound reasoning. This is the same line of argument picked by McGann and Johnstone (2006). Apparently an organisation is legitimate if it is legally accepted \& empowered to perform publicly required tasks (Gangl, Hofmann \& Kirchler, 2015). The concept stems from the principle of legal personality of the reporting entity (EU Regulation No 1290, 2013: Art 10 (1) (a-c)). Even donors are very keen on compliance with national laws (Murage, 2017:16).

Major donors like the US, UK, German, and the EU require that an NGO be registered in accordance with the law of the country of its establishment or operation for the "purpose and activities defined in its constitutive documents" (UNHCR, 2014: Art. 11.4). NGOs in Uganda are established following the guidelines prescribed by Uganda Registration Standards Bureau (URSB). The NGO Act, 2016 specifically focuses on the registration, management and governance of NGOs for operational purposes. Accordingly, all NGOs operating in the country, must have been incorporated and then, register with the National Bureau of NGOs under the Ministry of Internal Affairs (NGO Act, 2016: S. 29) and, obtain a valid operational permit (S.31). Some donors require a tax clearance certificate to consider a reporting entity legitimate (Okinda, 2013).

By October 2019, there are 14,027 NGOs operating in Uganda (Daily Monitor 15th Nov, 2019). This study regards NGOs as legitimately operating in Uganda if their activities are in line with the law and mutually agreed regulations with donors. Any organisations going against these legal requirements will be considered illegitimate. 2.3.2 Integrity

The Cambridge English Dictionary defines integrity as the quality of being honest and having strong moral principles. The word is associated with honesty, uprightness, righteousness, morality, ethics, trustworthiness, and sincerity. Integrity is viewed as the hallmark of sound moral and ethical principles in person's inner life. The European Research Administrators (2017) define integrity as the inner ability to avoid "any kind of fabrication, falsification, plagiarism, \& unjustified double funding". They argue that a person of integrity will be responsible, accountable, assertive, and loyal, and will manage impressions well.

Donors expect NGO managers in Uganda to conduct themselves ethically by not pursuing personal gain at 
the expense of their organisations, and refraining from exploiting and abusing beneficiaries. They must institute measures to investigate all forms of misconduct $\&$ take disciplinary or corrective action; exercise professional due care \& competency; respect labour regulations; and ensure personnel confidentiality (UNHCR, 2014: Art. 10.34). The Minister of disaster preparedness Eng. Hillary Onek cautions some NGO managers not to engage in lavish lifestyles instead of helping beneficiaries. The minister proposes that $80 \%-90 \%$ of donor funding should be applied to beneficiaries (programme activities) while 10-20\% be left for operations (administration costs) (The New Vision 8th March, 2018). This study defines integrity as a managerial spirit for goodwill and fair judgement beyond the written laws and contractual obligations signed with donors. Integrity should be reflected by the pattern of annual expenditure growth and audit opinions.

2.3.3 Transparency

Oxford English Dictionary defines it as "a situation in which business and financial activities are done openly without secrets, so that people can trust that one is fair and honest". In management, transparency refers to "willingness and ability to provide information" (Burger \& Owens, 2010). Omona and Mukuye (2013) defined transparency as "openness in handling finances and governance" issues. NGO transparency may include explicit acknowledgement of donor funds; properly documenting transactions; ensuring due diligence in procurements; carrying out background checks in recruitments; highlighting success stories; and planning open door stakeholder events as evidence of work done (Whitaker, 2017).

The need for transparency has never been more critical than in the 21 st Century. The global financial scandals in the corporate world like those at Enron and WorldCom have shaken the foundations of donor trust (Mcmurrian \& Matulich, 2016; Whitaker, 2017). These have come at a time when "we sadly live in an age when integrity and transparency seem outdated relics of a nostalgic past. Even those that we know well are sometimes less than honest", laments Prestol-Puesan (2020:12). For these reasons, donors can no longer take more chances!

The EU provides ethical principles to guide their interventions such as ethical procurements, sound financial management, impartiality, transparency, proportionality, avoiding conflicts of interest, supporting local economy and due diligence (EU Annex II, 2014: 3-6). These principles help EU implementing NGOs to be transparent. This study defines transparency as a system of unobstructed openness to stimulate stakeholder confidence in the way organisational affairs are managed. Transparency of NGOs in Uganda will be measured by openness in financial transactions and Clarity of programme activities.

\subsection{Ethical Behaviour and Compliance: A relationship}

The premise of this study is that ethical behaviour promotes compliance with donor reporting requirements, which attracts more donations in the economy. It is assumed that NGOs are free from the bureaucratic red tape of the public sector; the profit motive of the private sector; and the conflict of interest of the labour unions (Not-for-Profit Quarterly, 2018). However, absence of a profit motive does not seem to automatically translate into freedom from agency problems. NGO operations in Uganda tend to reveal material weaknesses in fraudulent procurements and financial management (The CSO Sustainability Index, 2017). Some studies indicate that ethical gaps have forced donors like German to withhold up to UGX 400 billion $(\$ 106 \mathrm{~m})$ for Uganda's refugee resettlement programme (Sunday Monitor June 9, 2019).

Perhaps one of the outstanding studies on unethical financial management was conducted by Krishnan, Yetman \& Yetman (2006) who cited evidence of obvious misreporting of information that NGOs give to stakeholders. The study sought to address the issue of whether the misreporting incidences "are due to random error, intentional manipulation, or some other factor". It was observed that the "inappropriate reporting behavior is consistent with managerial incentives". This suggests that the variance between what NGOs are expected to do and what they actually do, may be a function of managers pursuing own interests. Othman et al., (2012) seem to confirm this suspicion when they found that NGOs are subjects of abuses "perpetrated by their own managers and employees".

The point seems clear that ethical behaviour can influence managerial conduct. Weinstein (2012) suggests that behaving ethically is a prerequisite for managers to serve stakeholder interests. In addition, Turyakira (2018) observes that ethical principles influence personal values of managers and that measures such as sound business practices and personal integrity, result in meeting stakeholder expectations. Mayanja \& Perks (2018) point out that unethical behaviour retards an entity's compliance potential. Thus these writers commonly agree to the notion that an organisation's ability to comply is a function of managerial ethical values among other factors.

The issue is whether NGO managers in Uganda exhibit the necessary ethical behaviour to deliver on stakeholder common interests. Ethics and Compliance Initiative (2019) indicates that Managers enter into covenants of accountability and should be held responsible for acting selfishly or negligently. This study examines how the three selected ethical behavioural measures of legitimacy, integrity and transparency, alongside competent staffing, influence compliance with donor reporting requirements.

2.4.1 Legitimacy and compliance with donor reporting requirements

This study views legitimacy as the response to the legal, social, mutual and internal controls regulating NGO 
operations. Complying with this reporting requirement helps donors and implementers to track progress of an intervention, and enables other stakeholders to verify the assertions made in NGO reports. This is the genesis of complete, accurate and timely reporting (Omona \& Mukuye, 2010:316). Legitimacy lays the foundation of legal personality of a reporting entity, identifies the various parties, and forms the yardstick of measuring effectiveness towards stakeholder expectations (Murage, 2017).

NGOs operating in Uganda are expected to be incorporated, register with the National Bureau of NGOs, obtain operational permits, file tax returns and submit audited books of accounts eight months after end of financial year. The financial reports should be prepared in accordance with generally accepted accounting principles (NGO Act, 2016, sec 39). These are in addition to programme reports which show the effectiveness and output results of their interventions (Detiger, 2018). However, facts suggest that NGO operations are not legitimately aligned with the reporting requirements. According to the CSO Sustainability Index (2017) there are significant flaws and failures to comply with regulatory obligations by NGOs in Uganda.

The failure to respect the law is evidenced by the huge number of NGOs operating in the country without valid permits. By $31^{\text {st }}$ July 2019, 14,027 NGOs were established in Uganda, of which 10,379 (73\%) had expired registrations and only 3,810 (27\%) possessed valid registration certificates. The Ministry of Internal Affairs through the National Bureau of NGOs conducted a drive to authenticate which NGOs were operating legally. The move resulted in 2,119 turning up to get their permits renewed but 11,908 NGOs still remained invalidated by October 2019 (Daily Monitor 15th Nov, 2019). The media alleges that NGOs are reluctant to observe the legal requirements and to commit to any social contract. This study therefore hypothesizes that:

$H_{1}$ : Legitimacy as measured by registration and legal reporting has a significant positive relationship with compliance with donor reporting requirements.

2.4.2 Integrity and compliance with donor reporting requirements

Integrity is a virtual associated with honesty, uprightness, righteousness, morality, ethics, trustworthiness, and sincerity. Prestol-Puesan (2020) presented integrity as an asset of being honest and skewed towards moral and ethical principles. The argument is that written regulations and contractual obligations only serve as general standards of conduct but not a substitute for managerial integrity and good judgement. Ethics and Compliance Initiative (2019) adds that sometimes the written letters rarely spell out all appropriate responses to every situation that may arise, which makes integrity a valuable commodity.

Christakis \& Fowler (2011) contended that both good and bad behaviour is contagious. They argued that integrity could impact the social behaviour of a person's friends, associates or the people around. For instance, if one employee returns extra change from an over-calculated bill, it creates a precedence for others who might have tried to fake documents in order to present full accountability. This would ideally imply that integrity or lapses of integrity can spread among individuals or organisations. Actually, Othman et al., (2012:16) argue that management can be a good or bad example to limit or encourage employee involvement in financial malpractices. From the agency theory (Jensen and Meckling, 1976), managers may "manipulate financial statements and falsify other accounting records to satisfy their interests" (Kaawaase et al., 2016).

This is perhaps why several writers have found a positive relationship between managerial integrity and compliance with donor reporting requirements (Atan et al., 2012). Major humanitarian aid donors like UK and Germany threatened to freeze aid to Uganda until stringent integrity measures are instituted for the NGO sector (Okiror, 2019). Ethical management should not condone but be willing to investigate wrongdoing. Uganda's high moral decadency is reflected by willingness to give and receive bribes (UNDP-UG-Police-Report, 2019:20). The NGO sector is characterized by allegations of kickbacks and setting up some NGOs as "income generating entities" for the owners. Ideally, these integrity lapses could be responsible for the non-compliance with donor reporting requirements.

Anderson (2014:10) measured integrity using managerial willingness to institute internal controls, adhering to contract terms and then public trust. Deviations from such measures would imply managerial integritydeficiency. This study tests the end-result of measures used by Anderson such as annual expenditure growth which shows donor confidence and programme effectiveness, plus audit outcomes as a test of efficiency. It is thus hypothesized that:

$\mathrm{H}_{2}$ : Integrity as measured by annual expenditure growth and audit opinion has a significant positive relationship with compliance with donor reporting requirements.

2.4.3 Transparency and compliance with donor reporting requirements

This study defines transparency as a system of unobstructed openness that kindles stakeholder confidence in organisational affairs. Prestol-Puesan (2020) affirms that transparency bears the qualities of openness, authenticity, clarity and understandability, and should eliminate ambiguity. This in effect is the principle of fair presentation advanced by the International Accounting Standards Board (IASB framework, 2018). For financial information to be fairly presented, it must be reliable, comparable and understandable. Grabiel \& Saint-Cyr (2018) observe that transparency results in complete, accurate and timely reporting which improves the NGO-donor relationship.

Burger \& Owens (2010) found that $69 \%$ of NGOs mis-represented information for reasons of attempting to 
hide corrupt and ineffective behaviour from donor scrutiny. One way of hiding information from stakeholders is lack of documentation. A case in point is where a Ugandan NGO could not sufficiently support an expense of $\$ 272,000$ (Sunday Monitor June 9, 2019). Remember absence of documents creates suspicions for fraud due to lack of audit trail, impedes planning, and could lead to loss of donor funding (Buljubašić \& Erkan, 2015). Loss of donor funding is what perhaps Othman \& Ali (2012) had in mind when they argued that every time an organisation fails to be transparent, it becomes a threat to its own existence!

Rukare (2019, cited in Sunday Monitor June 9, 2019) laments that "NGOs which should be a model of transparency, are themselves infested with similar unethical challenges". In Uganda, NGOs have been accused of wasting millions of dollars in mismanaged operations, improperly awarded contracts and overpaid bills, (Okiror, 2019). Lack of transparency is also demonstrated by failure or delayed reporting and interpreted as attempts to conceal evil behaviour in financial management. As Prestol-Puesan (2020) emphasized, transparency grows from the stem of ethical behaviour. Mere promises to strengthen accountability may not yield better media reports (Mbiyozo, 2019). This study hypothesizes that:

$H_{3}$ : Transparency as measured by prior beneficiary consultations and public access to NGO financial reports has a significant positive relationship with compliance with donor reporting requirements.

\subsection{Competent staffing and compliance with donor reporting requirements}

Competent staffing refers to a system of stocking the organisation with qualified, experienced, and motivated personnel to facilitate complete, accurate and timely reporting. The NGOs are encouraged to employ qualified staff, whose criminal record has been or can be verified by the National Bureau of NGOs (The NGO Act, 2016: S.45). This is based upon the assumption that competent staffing is a key influencer to meeting donor reporting requirements and other stakeholder interests like tax computations (Saxton, Kuo \& Ho, 2011; Mayanja \& Perks, 2018; Tusubira, 2018). This need seems to increase with the volume of funding, size of the organisation and transactions that require judgement.

Fifty out of the 104 cases (48\%) studied by Burger \& Owens (2010), reveal careless mistakes that could be detected by competent managers. They indicated that the reporting inaccuracies found were due to staffing issues such as staffing levels, qualifications and age of the manager. Othman et al. (2012) actually highlighted inexperienced staff and inappropriate reporting (resulting from managerial interests) as challenges of NGOs in developing countries. Accordingly, NGOs will be judged incompetent when the information presented is incomplete, delayed, or deviates from acceptable guidelines.

The struggle to have competent staff may require regular training and retention strategies that prevent high turnover trends. Badaru (2012) recommended increased frequency of performance review workshops as a catalyst for timely reporting. The Norwegian Refugee Council (2016) specified qualified, experienced and ethical personnel as necessary to attain complete, accurate and timely reporting. The World Bank Global AIDS M \& E model (2017) emphasizes staffing levels and support supervision as a way of complying with reporting requirements. This study hypothesizes that:

$\mathrm{H}_{4}$ : Competent staffing as measured by staff academic qualifications and work experience has a significant positive relationship with compliance with donor reporting requirements.

\subsection{Summary of the literature}

This study promotes ethical behaviour as a compliance tool, notwithstanding the ambiguity of NGO operations and availability of every pretext for pursuing personal interest.

\section{Methodology}

This section looks at how the researcher will obtain the relevant data required to accomplish the study, and it includes the research design, study population, sample size and selection techniques, data sources, data collection instruments, plus data processing and analysis tools.

\subsection{Research design}

Due to limited studies on NGO compliance in Uganda, and especially as a result of ethical behaviour, this study will use exploratory and descriptive cross-sectional approaches. These employ both quantitative and qualitative research methods to describe the present situation as they pursue the study objectives. Accordingly, data will be collected to generate both quantitative and qualitative analyses of the respondents' perceptions on how ethical behaviour as it relates to NGOs' compliance with donor reporting requirements. Due to limited movements as a result of COVID-19 pandemic, the researcher will use online administered questionnaires to collect the data. This will still help the researcher to gain sufficient understanding of the subject of study without endangering himself or the respondents. 


\subsection{Study population}

The study population will comprise of the NGOs incorporated or established in and outside Uganda, but with valid permits to operate in the country. In Uganda, the NGOs can be categorised as international, continental, regional, national, or community based organisations (The NGO Act, 2016). They can as well be classified as humanitarian, development or civil society organisations, depending on what they are permitted to undertake. Integral to the NGO fraternity, they are both donor agencies and their implementing partners.

According to the National Bureau of NGOs under the supervision of the Ministry of Internal Affairs, the number of NGOs with valid permits in Uganda as of $7^{\text {th }}$ September 2019 is 2,119 (New Vision October 1, 2019). The researcher will consider the donor agencies with operational offices in Uganda as well as the implementing NGOs that they fund as the unit of analysis. The unit of inquiry on the other hand, will be the heads of programs/grants management, compliance \& internal audit and finance \& administration of the donor agencies and their implementing partners.

\subsection{Sample selection}

The sampling process is guided by previous studies on NGO compliance in Uganda and the region such as by Badaru (2012), Omona \& Mukuye (2013), Anderson (2014), (Yakubu, 2016), CSO Sustainability Index (2017), Damba (2018), among others. Ideally, the central principle is to get data from both the donor agency and the implementing NGO. This method is deemed appropriate in this study due to the sensitivity of the information that raises a possibility of getting inaccurate data, hence obtaining same data from two sources will mitigate this risk. Donor agencies and their implementing partners in Uganda will purposively be sampled and online-administered questionnaires used to collect data. As was the case from the previous studies cited above, the same method will be employed to sample the units of inquiry from these entities. Since compliance as influenced by ethical behaviour is a managerial aspect, senior management heads such as heads of programs/grants management, compliance/internal audit, finance \& administration, or the equivalent positions, will be target respondents to give representative and generalisable information.

\subsection{Sample size}

For generalisations about the study populations to be appropriate, researchers usually pick samples from such populations. The sample is basically determined using some random procedures, so long as the population size can be estimated (Anderson, 2014; Tusubira, 2018). The present study has adopted the Krejcie \& Morgan (1970: 608) table below when determining the sample size. The table provides sample size(s) for each corresponding population size.

Table 1: Population and sample size (at 95\% level of confidence)

\begin{tabular}{|c|c|c|c|c|c|c|c|c|c|}
\hline $\mathrm{N}$ & $\mathrm{S}$ & $\mathrm{N}$ & $\mathrm{S}$ & $\mathrm{N}$ & $\mathrm{s}$ & $\mathrm{N}$ & $\mathrm{s}$ & $\mathrm{N}$ & $s$ \\
\hline 10 & 10 & 100 & 80 & 280 & 162 & 800 & 260 & 2800 & 338 \\
\hline 15 & 14 & 110 & 86 & 290 & 165 & 850 & 265 & 3000 & 341 \\
\hline 20 & 19 & 120 & 92 & 300 & 169 & 900 & 269 & 3500 & 346 \\
\hline 25 & 24 & 130 & 97 & 320 & 175 & 950 & 274 & 4000 & 351 \\
\hline 30 & 28 & 140 & 103 & 340 & 181 & 1000 & 278 & 4500 & 354 \\
\hline 35 & 32 & 150 & 108 & 360 & 186 & 1100 & 285 & 5000 & 357 \\
\hline 40 & 36 & 160 & 113 & 380 & 191 & 1200 & 291 & 6000 & 361 \\
\hline 45 & 40 & 170 & 118 & 400 & 196 & 1300 & 297 & 7000 & 364 \\
\hline 50 & 44 & 180 & 123 & 420 & 201 & 1400 & 302 & 8000 & 367 \\
\hline 55 & 48 & 190 & 127 & 440 & 205 & 1500 & 306 & 9000 & 368 \\
\hline 60 & 52 & 200 & 132 & 460 & 210 & 1600 & 310 & 10000 & 370 \\
\hline 65 & 56 & 210 & 136 & 480 & 241 & 1700 & 313 & 15000 & 375 \\
\hline 70 & 59 & 220 & 140 & 500 & 217 & 1800 & 317 & 20000 & 377 \\
\hline 75 & 63 & 230 & 144 & 550 & 226 & 1900 & 320 & 30000 & 379 \\
\hline 80 & 66 & 240 & 148 & 600 & 234 & 2000 & 322 & 40000 & 380 \\
\hline 85 & 70 & 250 & 152 & 650 & 242 & 2200 & 327 & 50000 & 381 \\
\hline 90 & 73 & 260 & 155 & 700 & 248 & 2400 & 331 & 75000 & 382 \\
\hline 95 & 76 & 270 & 159 & 750 & 254 & 2600 & 335 & 100000 & 384 \\
\hline
\end{tabular}

Source: Krejcie \& Morgan (1970: 608)

The Krejcie and Morgan (1970) formula to achieve representation of the population of interest is derived from the following formula:

Sample size $=$

$$
\mathrm{d}^{2}(\mathrm{~N}-1)+\frac{\mathrm{X}^{2} \mathrm{~N} P(1-\mathrm{P})}{\mathrm{X}^{2} \mathrm{P}(1-\mathrm{P})}
$$

Where;

$\mathrm{X}^{2}=$ the table value of chi-square for 1 degree of freedom at the desired confidence level 
$\mathrm{N}=$ population size

$\mathrm{P}=$ Population proportion (assumed to be $50 \%$ since this would provide the maximum sample size)

$\mathrm{d}^{2}=$ the degree of accuracy expressed as a proportion

In this study, $\mathrm{N}=2119$

$$
\begin{aligned}
& P=0.5 \\
& d=0.05 \text { at the } 95 \% \text { degree of confidence } \\
& X=1.96
\end{aligned}
$$

Thus sample size $=\quad \underline{1.96^{2} * 2119 * 0.5(1-0.5)}=\underline{0.0325}$

$0.05^{2}(2119-1)+1.96^{2} * 0.5(\overline{1-0.5)} 5.295+0.9604$

From the analysis, 325 respondents would be the minimum sample for the study. Due to the indivisibility of this number to the units of analysis however, the figure will be rounded upwards to 327 respondents. The study will thus identify three (3) staff members from each of the 14 donor agencies, giving 42 respondents. In addition, data will be obtained from three (3) senior management members of ninety-five (95) selected implementing partners in and around Kampala and Wakiso political Districts. As it were, the respondents will be selected from among heads of programs, finance \& administration, compliance \& internal audit, human resource, as well as project and grants managers. This results in 285 respondents, which is added to the 42 agency respondents to give a total sample size of 327 respondents.

\subsection{Source and types of data}

The study data will be collected from both primary and secondary sources. The researcher will also collect data from each of the three (3) NGO platform organs - National Bureau of NGOs, Uganda national NGO Forum and Office of the Prime Minister (OPM) Refugee Desk. Data from these organs will be used to benchmark and augment information collected from the donor agencies and their respective implementing partners (IPs). On the other hand, secondary data will be obtained from published reports available on websites of the NGO platform organs, donor agencies, implementing NGOs and other government agencies.

\subsection{Data collection instruments}

The researcher will use online self-administered questionnaires and interview guide to collect primary data and online access of published secondary data available on the websites.

\subsection{Data collection procedure and analysis}

The researcher will distribute the questionnaires to the selected organisations and donor agencies through e-mail and Internet online service. This data will be cleaned, coded within a spreadsheet and exported to and analysed using a statistical package for social scientists (SPSS) Version 23 and STATA for the secondary data. The results of the analysis will take the shape of frequency counts, arithmetic mean scores, correlations and regressions among other measures deemed necessary.

\section{References}

Arai, T., Aiyama, Y., Sugi, M. \& Ota, J. (2001), "Holonic Assembly System with Plug and Produce”, Computers in Industry 46, Elsevier, 289-299.

Bell, G.A., Cooper, M.A., Kennedy, M. \& Warwick, J. (2000), "The Development of the Holon Planning and Costing Framework for Higher Education Management”, Technical Report, SBU-CISM-11-00, South Bank University, 103 Borough Road, London, SE1 0AA.

Bongaerts, L. (1998), "Integration of Scheduling and Control in Holonic Manufacturing Systems", PhD Thesis, PMA Division, K.U.Leuven.

Deen, S.M. (1993), “Cooperation Issues in Holonic Manufacturing Systems”, Proceedings of DIISM’93 Conference, 410-412.

All European Academies (2013). Ethics Education in Science. The Permanent Working Group on Science and Ethics. www.allea.org/wp-content/uploads/2015/07/Statement_Ethics_Edu_web_final_2013_10_10.pdf

Anderson F, O. (2014). “The Nascent Nonprofit Organization-What Happens Before a Nonprofit Is 'Born'?” in this edition, Nonprofit Quarterly.

Anderson L.B. (2014), “The impact of donors' reporting requirements on NGO decision-making and projects in post-disaster housing reconstruction", Masters Dissertation, University of Illinois Urbana-Champaign, Fall 2014, New Jersey.

Atan, R., Zainon, S., \& Wah, Y. B. (2012). Quality information by charity organizations and its relationship with donations. In recent advances in business administration (118-123).

Badaru, M. J. A. (2012). Factors Affecting Compliance with Donor Reporting Requirements by Implementing Partners: A Case Study of the Inter- Religious Council of Uganda HIV/AIDS Programme, UMI Kampala 
Uganda.

Barr A., Fafchamps M., \& Trudy O. (2005). A report to the Government of Uganda on Non-Governmental Organizations in Uganda. Centre for the Study of African Economies, Department of Economics, Oxford University.

Buberl T., (2018). AXA Compliance \& Ethics Code. AXA SA, 25 avenue Matignon 75008, Paris.

Buberl T., (2019). Compliance and Ethics code. https://www.axa.com/en/newsroom/publications/complianceethics-guide.

Burger, R.; Owens, T. (2010), "Promoting transparency in the NGO sector: Examining the availability and reliability of self-reported data". https:/www.econstor.eu/obitstream/10419/65448/1/595031048.pdf.

CEO Forum, (2018), "Making economic growth inclusive, equitable \& sustainable: Increasing private sector competitiveness", $9^{\text {th }}$ edition.

Christakis N. \& Fowler J., (2011), "The Social Power of Integrity". The Atlas Society. https://atlassociety.org/objectivism/atlas-university/personal-application-blog/4813-the-social-power-ofintegrity.

Damba R. (2018), “Of What value are NGOs to Uganda?" Available at https://www.ngoforum.or.ug/2018/05/30/of-what-value-are-ngos-to-uganda

Danish Refugee Council (2018), "Funding gaps threaten critical aid for refugees in Uganda". https://drc.ngo/news/funding-gaps-threaten-critical-aid-for-refugees-in-uganda

Detiger E. (2018), "Mechanisms to Ensure Accountability". https://www.fundsforngos.org/featured-articles/howto-make-your-organization-accountable.

Dupuy K., \& Prakash A., (2017), "Do Donors Reduce Bilateral Aid to Countries with Restrictive NGO Laws? A Panel Study, 1993-2012”. Nonprofit and Voluntary Sector Quarterly, 47(1) 89-106.

EU Regulation No 1290 (2013), "Horizon 2020 - the Framework Programme for Research and Innovation (20142020)". Official Journal of the European Union, L 347/81

European Research Administrators (2017), "Guidelines for Ensuring Compliance with Ethical Principles in Horizon 2020 - from Proposal to Grant Agreement".

Gangl, K., Hofmann, E., de Groot, M., Antonides, G., Goslinga, S., Hartl, B., \& Kirchler, E. (2015). Taxpayers' Motivations Relating to Tax Compliance: Evidence from Two Representative Samples of Austrian and Dutch Self-Employed Taxpayers. Journal of Tax Administration, 1(2), 15-25.

Global Business Ethics Survey (2019), "The Link between Supervisor Leadership and Workplace Behaviors: A Global Look". Ethics \& Compliance Initiative, ISBN 978-1-7923-2894-7. Vienna VA 22180

Grabiel T-M., \& Saint-Cyr E., (2018), “Audit of UNESCO’s Compliance with Donor Agreements". Internal Oversight Service Audit Section, IOS/AUD/2018/03 Original.

Humentum (2019), "Best Practices Managing Donor Funding" available at https://www.humentum.org > bestpractices-managing-donor-funding, accessed on $11^{\text {th }}$ October 2019 at 16:11 hours.

Inspectorate of Government (2017), "Inspectorate of Government Report to Parliament January - June 2017".

International Rescue Committee (2018), "A New Response to the Protracted Refugee Crisis in Uganda: A case study of World Bank financing for refugee-hosting nations". International Rescue Committee | November 2018, Washington, DC 20036.

Ishita R., Tanzil A. R., \& Sarker A. K. (2017), "Contribution of NGOs for Socio-Economic Development in Bangladesh". Science Journal of Business and Management, 5(1), 1-8. doi: 10.11648/j.sjbm.20170501.11

Jensen, M.C. \& Meckling, W.H. (1976), "Theory of the Firm: Managerial Behavior, Agency Costs, And Ownership Structure". Journal of Financial Economics, 3(4), 305-360.

Joint Inspection Unit (2017), "Review of Donor Reporting Requirements across the United Nations System". JIU/REP/2017/7 Original: English. Geneva.

Kaawaase, T.K., Assad, M.J., Kitindi, E.G. \& Nkundabanyanga, K.S. (2016), “Audit Quality Differences Amongst Audit Firms in A Developing Economy: The Case of Uganda". Journal of Accounting in Emerging Economies, 6(3), 269-290.

Kanaga R., (2018), "Ways to Improve Donor Reporting Across United Nations System". http://www.socialwatch.org/node/18032. Quoting report (JIU/REP/2017/7)

Knott B., (2020), "The Church I Want to Belong to is Ethical". Adventist World Bulletin, March 2020. www.adventistworld.org/march2020/

Krejcie \& Morgan (1970), "Determining Sample Size for Research Activities. Educational and Psychology Measurement, 30, 607-610.

Krishnan R., Yetman H. M., \& Yetman R. J., (2006), “Expense Mis-reporting in Nonprofit Organization”. The Accounting Review, 81(2), 399-420.

Lehman, G. (2007), “The Accountability of NGOs in Civil Society and its Public Spheres". Critical Perspectives on Accounting, 18, Elsevier 645-669.

LIM R., (2019), “Top 10 Main Causes of Project Failure”. Published by project management.com. https://project- 
management.com/top-10-main-causes-of-project-failure/

Llott G. L., (2017), "Define Positive Accounting Theory and Explain Its Development". Article available at https://www.slideshare.net/GerardIlott/lo61-define-positive-accounting-theory-and-explain-its-development

Machuki, V. N., (2010), "Corporate Governance Structures and Performance of HIV/AIDS NGOs". Nairobi School of Business, University of Nairobi, Kenya.

Makoba, J. (2002), "Nongovernmental Organizations (NGOs) and Third World Development: An Alternative Approach to Development". Journal of Third World Studies, 19(1), 53-63.

Mayanja J. \& Perks (2018). "Business Environment Factors Influencing Ethical Business Conduct of Small and Medium-Size Businesses in Uganda”. Journal of Contemporary Management, 14, 1064-1096.

Mbiyozo A.N., (2019), "How Uganda and UNHCR Failed Refugees, Major Fraud and Corruption in Uganda's Operations Will Come at A Steep Cost to All Refugees”. Institute for Security Studies.

McGann, J.; Johnstone, M. (2006), "The Power Shift and The NGO Credibility Crisis". International Journal of Not-for-Profit Law, 8(2), 65-77.

Mcmurrian R. C. \& Matulich E. (2016), "Building Customer Value and Profitability with Business Ethics". Journal of Business and Economics Research, 14(3), 83-90.

Meyer, C. (1992), “A Step Back as Donors Shift Institution Building from The Public to The "Private" Sector". World Development, 20(8), 1115-1126.

MFPED (2017). Boosting investor confidence for enterprise development and industrialisation. The national strategy for private sector development (FY 2017/18-FY 2021/22).

Muhenda (2017). Uganda Fears NGO Big Money. https://www.independent.co.ug/uganda-fear-ngo-big-money/ Sept 27, 2019.

Mukokoma \& Tushabomwe (2019). "Enablers and Inhibitors of IFRS for SMEs' Adoption in Uganda". ICPAU, Kampala.

Mulyagonja I. (2013), "IGG: Political Interference Favours the Big Thieves". The Observer. https://observer.ug/component/content/article?id=23866:igg-political-interference-favours-the-big-thieves.

Murage C.K. (2017). "Compliance Review Audits and Financial Performance of Donor Funded Organisations in Nyeri County, Kenya". Masters Dissertation, Kenyatta University, Nairobi Kenya.

Government of Uganda (2016). Laws of the Government of the Republic of Uganda, NGO Act, cap 113, Kampala. OECD, (2003). Harmonising Donor Practices for Effective Aid Delivery - ISBN 92-64-19982-9

Okiror, S., (2019). Key Donors Freeze Uganda Refugee Aid After UN Mismanagement Scandal. The New Humanitarian, Issue 28 February 2019.

Omona, A. M. (2008), “Assessment of the Level of Compliance with IFRSs by Firms in Uganda", Masters Dissertation, Makerere University, Kampala.

Omona J. \& Mukuye R. (2013). Problems of Credibility of NGOs in Uganda: Implications for Theory and Practice. International Journal of Voluntary and Nonprofit Organizations, 24(2), 311-334. Springer available at: https://www.jstor.org/stable/42629812

Othman, R., \& Ali, N., (2012), "NPO, Internal Controls, and Supervision Mechanisms in a Developing Country". VOLUNTAS: International Journal of Voluntary and Nonprofit Organizations, 25(1), 201-224.

Othman, R., Ali, N., Omar, N., \& Rahman R., A., (2012), "Practical Challenges in Managing Non-Profit Organizations (NPO): Tales from Two Neighbouring Countries. International Bulletin of Business Administration, 13, 6-18.

Pigou A., (1938). The Economics of Welfare, 4th ed. London: Macmillan.

Poole, L., (2019), "The Refugee Response in Northern Uganda: Resources Beyond International Humanitarian Assistance". Humanitarian Policy Group, Overseas Development Institute, London.

Prestol-Puesan J., (2020), "The Church I Want to Belong to is Ethical". Adventist World Bulletin, March 2020. www.adventistworld.org/march2020/

Price N., (2017). Ethical Behaviour for Board Members is Culturally Driven. BoardEffect.com, August 9, 2017. www.boardeffect.com/blog/ethical-behaviour-board-members-culturally-driven/

Saxton, G. D., Kuo, J. S., \& Ho, Y. C. (2011). The Determinants of Voluntary Financial Disclosure by Non-profit Organizations. Nonprofit and Voluntary Sector Quarterly.

The Daily Monitor newspaper (SUNDAY JUNE 9 2019), "Donors freeze funding to NGOs over corruption".

The New Vision newspaper (Tuesday October 1, 2019), "Researchers blame NGOs for not doing their work".

The World Bank, UNHCR \& the Government of Uganda (2016). An Assessment of Uganda's Progressive Approach to Refugee Management. Washington D.C.: The World Bank Group.

The World Bank (2018). International Development Association Project Appraisal Document on a Proposed Credit and a Proposed Grant to the Republic of Uganda for the Integrated Water Management and Development Project.

Turyakira, P. K. (2018). Ethical Practices of Small and Medium-Sized Enterprises in Developing Countries: Literature Analysis. South African Journal of Economic and Management Sciences, 21(1), a1756. 
http://dx.doi.org/10.4102/sajems.v21i1.1756.

Azia, D. (2018), “The Integrated Response Plan for Refugees from South Sudan, Burundi and the Democratic Republic of the Congo January 2019-December 2020". Uganda Country RRP

UNHCR (2014), "Bipartite Model: Standard Format Bipartite Project Partnership Agreement". UNHCR with Nongovernmental and Other Not-for-profit partners.

USAID (2010). The Essential NGO Guide to Managing Your USAID Award. United States Agency for International Development. NW Washington, DC 20009-5721, 64-65.

Wade J., (2011), "The Social Power of Integrity". The Atlas Society. Accessed from: https://atlassociety.org/objectivism/atlas-university/personal-application-blog/4813-the-social-power-ofintegrity.

Walakira J., (2019), "Why NGO Funding Should Concern Government. Mulengera News Paper. Accessed from: https://mulengeranews.com/why-ngo-feuding-shd-concern-government/

Watts R. L., \& Zimmerman J. L. (1978), “Towards a Positive Theory Of The Determination Of Accounting Standards. Accounting Review, 53(1), 112-134.

Waxenberger B., (2003), "Framework for Ethically Aware Businesses: The Integrity Management Model. In: Wieland J. (eds) Standards and Audits for Ethics Management Systems". Ethical Economy (Studies in Economic Ethics and Philosophy), Springer, Berlin, Heidelberg. https://doi.org/10.1007/978-3-662-051078_11.

Weinstein, A. (2012), “Superior Customer Value: Strategies for Winning and Retaining Customers". Third Edition, Boca Raton, Florida: CRC Press-Taylor \& http://dx.doi.org/10.17010/ijom\%2F2013\%2Fv43\%2Fi4\%2F36381

Whitaker, T. C. (2017), "What Today’s Donor Wants: Managing Expectations and Measuring Impact". Accessed on 11 October 2019. Available at https://www.nonprofitpro.com/article/todays-donor-wantsmanaging-expectations-measuring-impact/

Yakubu, B. I. (2016), "Measuring Aid Effectiveness: An Analysis of Beneficiary Perspectives". UDS International Journal of Development, 2(2), 109-120.

Yiadom, E. M., \& Atsunyo, W. (2014), "Compliance with International Financial Reporting Standards by Listed Companies in Ghana". International Journal of Business and Management, 9(10), 87-100.

Zainon, S., Atan, R., Wah, Y. B., \& Nam, R. Y. T. (2011), “Institutional Donors' Expectation of Information from The Non-Profit Organizations (NGOs) Reporting: A Pilot Survey”. International NGO Journal, 6(8), 170180. 